\title{
Common Currency Area in GCC Region: An Application of Euro Model
}

\author{
Waqar Ahmad \\ Department of Industrial Engineering, King Abdul Aziz University, Jeddah, KSA \\ Email:Wahmed@kau.edu.sa
}

How to cite this paper: Ahmad, W. (2021). Common Currency Area in GCC Region: An Application of Euro Model. American Journal of Industrial and Business Management, 11, 905-923. https://doi.org/10.4236/ajibm.2021.118055

Received: July 23, 2021

Accepted: August 17, 2021

Published: August 20, 2021

Copyright (C) 2021 by author(s) and Scientific Research Publishing Inc. This work is licensed under the Creative Commons Attribution International License (CC BY 4.0).

http://creativecommons.org/licenses/by/4.0/

\begin{abstract}
US Dollar (USD) is the most dominant currency encompassing $59.54 \%$ of the world reserve currency. Euro is the second one, which holds $20.57 \%$ share of world reserve currency. The recent studies reveal that the USD might not be the dominant world reserve currency in the future. Euro as a common regional currency is the only competitor of USD, which shows the strength of a unified regional currency. In 1981, the six rich oil states formed Gulf Cooperative Council (GCC); the countries include the Kingdom of Saudi Arabia, the State of Qatar, the Sultanate of Oman, the Kingdom of Bahrain, the State of Kuwait, and the United Arab Emirates. This establishment of GCC signifies the close cultural, economic and political link between the GCC countries. GCC countries have almost all essential ingredients required to establish a common currency area or monetary union. The researcher applied the European Monetary Union (EMU) model to GCC states to find out the feasibility of a common currency or monetary union between GCC states. Currently, EMU is the only example of successful implementation of common regional currency founded on Mundell's theory of Optimum Currency Area (OCA). The results obtained indicate that all the GCC states successfully fulfill the Euro criteria which are also called Maastricht criteria. The research has established that GCC countries are ripe for establishing a monetary union, especially if they follow the steps of EMU.
\end{abstract}

\section{Keywords}

EMU, GCC, Convergence Criteria, Triangular Arbitrage

\section{Introduction}

History of money and currency is closely associated with the history of civilizations. Ancient civilizations which flourished and dominated the Globe were using money and currency systems in one way or another. The transition from the 
barter system to the currency system marked an excellent stage of human history. Every piece of material, from crude metal pieces to silver, gold, and paper, has been used as currency. The only exception was probably "vegetables" for a valid reason because vegetables decay over time! Thus anything that has some intrinsic value and would survive over time could have been used as currency. Now the digital world is witnessing virtual money or digital cash in the form of credit cards, debit cards, and so on.

When the British Empire was at the pinnacle of its pomp and glory during the nineteenth and the first half of the twentieth century, British Pound held the status of an international currency. After the decline of British rule, the USD has been the leading currency in the world. The European countries, after fighting several wars, realized the importance of unity. The establishment of the European Union (EU) was the result of that realization. After the formation and effectiveness of the EU, over time, the European countries reached the establishment of monetary union. They signed the Maastricht Treaty in 1991 and agreed to form the monetary union, which led to the formation of the Euro currency as one of the strong competitors of the USD. The Euro is now the world's second top reserve currency.

Rich Arab countries with a lot of homogenous and favorable factors also realized the importance of unity. The six countries, namely the Kingdom of Saudi Arabia, the State of Qatar, Sultanate of Oman, United Arab Emirates, the State of Kuwait, and the Kingdom of Bahrain, set a Cooperation Council for the Arab States of Gulf (CCASG) which is also popularly named as Gulf Cooperation Council (GCC) on May 25 $25^{\text {th }}$ 1981/Rajab $21^{\text {st }} 1401$ AH. The formation of GCC was also for the purpose of cooperation among different arenas of life.

The GCC countries have a lot of homogeneity in cultural, social, religious, and historical values. Along with these factors, geographic proximity also plays a key role in increasing the interaction between GCC states. On top of it, the Greater Arab Free Trade Agreements (GAFTA) is one of the main substantial and broad agreements for the Arab and GCC countries' monetary and economic integration. GCC aims to bring the citizens of all countries closer and establish more collaboration towards the economy, trade, finance, administration, legislation, agriculture, etc. To achieve these objectives, the GCC Supreme Council has set many milestones such as:

1) The free export and import of industrial, agricultural, and natural resource products among GCC member states.

2) To developed unified trade policies among GCC countries to create a balance between trade terms and relations.

3) To make sure that there is a free movement of capital and citizens in the GCC states.

4) All GCC member states should coordinate with other GCC states while developing monetary, financial and banking strategies to boost collaboration among central banks and monetary agencies.

The GCC has achieved many milestones since its formation, but the concept 
of common currency among GCC states still remains a dream-come-true desire.

In this paper, the researcher adopts the criteria behind the formation of the Euro, to establish a common currency in GCC countries. The Euro model, which is the essence of the Maastricht Treaty of 1991, set basic rules for joining the monetary union. The researcher applied the rules of the Maastricht Treaty on the GCC states to find the viability of common currency. The researcher also set the value of the proposed currency, which previous researchers ignored. The exchange rate among GCC local currencies and proposed currency is set using the same mechanism of EMU.

Section two of this paper will provide a literature review, and section three will explain the implementation of EMU criteria in GCC countries. All the criteria of EMU will be explained separately in each subsection of section three. Section four elaborates the Exchange rate mechanism for the proposed common currency, and finally, section five concludes the findings.

\section{Literature Review}

After the formation of EMU, many researchers conducted different studies to study the benefits of a common currency. The concept of monetary union on a regional level was first presented in the Theory of Optimum Currency Area (OCA) by Nobel laureate Robert Alexander Mundell (Mundell, 1961). Mundell states in his theory that

"If the world can be divided into regions within each of which there is factor mobility and between which there is factor immobility, then each of these regions should have a separate currency that fluctuates relative to all other currencies (Mundell, 1961)"

Further extension in the OCA theory was done by McKinnon (1963), who suggested the addition of another criterion known as "openness of economy." Yet another addition was made by Kenen (1969), who recommended "economic diversification" criteria to be added in OCA theory. According to Kenen (1969) diversified economies are more likely to have interconnected or similar economic shocks, which are more effective if responded with a standard or common policy. Head and Mayer (2014) and Baldwin and Taglioni (2007) again revised this theory in 2007 and 2014. Gulzar (2015) also enriches this theory by adding other criteria, culture homogeneity.

Also, many researchers criticize the OCA theory. Priewe (2007) criticizes the OCA theory for not considering currency areas between countries of different levels of development. Siroën (2004) also criticized the OCA theory for underestimating the importance of the single currency as a public good for better international negotiation and other benefits that the national currency does not permit.

In early times Rose (2000) proposed a significant model using a dummy coefficient to find out the benefits for the countries using a common currency. The model finds that "bilateral trade between two countries that use the same cur- 
rency is 200 percent better than bilateral trade between countries that use different currencies". And many other researchers of the same era Frankel and Rose (2002), Lopez Cordova and Meissner (2001) and Flandreau and Maurel (2001) all arrived at the same results. Their studies revealed an increase of 100\% to $290 \%$ in trade for countries sharing a common monetary union. In a later follow-up study, Rose (2008) estimates the EMU effect by using 26 research, which later on extended by Havranek (2010) using the sample of sixty-one studies out of that thirty-three for other countries and twenty-eight was for EMU.

Although lately, De Sousa (2012) claims that the effect of monetary unions on trade decreases over time. Flam and Nordstrom (2006), De Nardis et al. (2008a, 2008b), Berger and Nitsch (2008), Baldwin and Taglioni (2007), Baldwin et al. (2008) and Santos Silva and Tenreyro (2010) has also support De Sousa.

Glick and Rose (2016) studied the effect with the more extensive data and models to find the claim by the researcher on their initial study and concluded that EMU boosted their trade after EMU. They find out that differences in the effects assessment results are likely due to differences in estimation methods. Glick (2017) also concluded that the EU has considerably boosted exports after the formation of EMU.

Boston and Firtescu (2019) also concluded that interest rates affect the financial markets and create a competitive environment. Different researchers have also studied that there is an effect of EMU on exchange rate on investment, exports, employment growth, capital markets, and inflation (Ioan et al., 2020; Dal Bianco \& Loan, 2017; Schnabl, 2008; Allen et al., 2016; Latief \& Lefen, 2018; Rjoub, 2012; Hatmanu et al., 2020; Jamil et al., 2012; Alagidede \& Ibrahim, 2017; Vo \& Zhang, 2019).

In addition to the improved trade among countries, there are many other offshoot benefits of a monetary union. Bergsten and Park, (2002) point out the complementary result of increased trade and enhanced financial integration as a benefit of a monetary union. The risks encountered by a standalone country in trading activities are discussed by Eichengreen and Hausmann (1999). They call it "the original sin" which is the incapability of a corporation or a country to raise or issue debt denominated in its currency. This type of incapability can cause broad exchange rate exposure and severe maturity mismatches. A regional monetary union can eliminate or at least reduce these inadequacies (Bergsten \& Park, 2002).

The first successfully implemented example of monetary union in the world is the European Monetary Union (EMU). The establishment of a common currency in Europe was a long process. It started in 1957 with the "Treaty of Rome" and was followed by establishing the European Monetary System (EMS) in 1979. In 1986 the "Single European Act" was another achievement, and then the famous Maastricht treaty in 1991 defined the essential criteria and conditions for joining a monetary union. The European Central Bank (ECB) initiation in 1998 was the final step that made the monetary union possible in European Union (McIver, 2011). 
The Maastricht treaty defined the criteria which are: 1) Price Stability, 2) Fiscal Prudence, 3) Successful EMU membership, and 4) Interest rate. The price stability criterion stipulates that "each member country's inflation rate must not be more than the average inflation rate of the three best-performing member states. In case it exceeds, it should be less than $1.5 \%$ of the average inflation rate computed for the three best performing participant countries" (European Central Bank, 2021). In the Maastricht Treaty, the "fiscal prudence" suggests the condition that a country aspiring to become a member should not have any excessive deficit at the time of joining (Treaty, 1992). When the researcher explored further about this criterion, two salient points were exposed. The first is the condition that "the ratio of the planned or actual government deficit to GDP at market prices should not exceed 3\%"; and the second is that "the ratio of government debt to GDP at market prices should not exceed 60\%" (https://ec.europa.eu/commission/presscorner/detail/en/DOC_12_2 Access on 10-02-2021).

The third and the most complex criterion of EMU was to adjust the exchange rates among different domestic currencies and the newly formed currency Euro. This criterion states that "each member country must have stayed within the normal fluctuation margins provided by the ERM of the Regional Monetary System, for at least two years, without devaluing against the currency of any other Member State". After further study, the researcher discovered that European Union used the triangular arbitrage method to calculate the exchange rate between Euro and local/domestic currencies (Gębarowski et. al., 2019).

The fourth and last criterion of the Maastricht treaty is associated with the interest rate. This criterion states that "a member state must have had an average nominal long-term interest rate that does not exceed by more than two percentage points that of, at the most, the three best performing member states in terms of price stability (interest rates are measured on the basis of long term government bonds or comparable securities)" (European Central Bank, 2021).

The successful implementation of the EMU and the introduction of the Euro currency had renewed the discussion of a monetary union in the GCC region. The close relations of GCC countries can be discerned in the formation of the Gulf Cooperation Council (GCC) in 1981 and the establishment of Greater Arab Free Trade Agreements (GAFTA) in 1997. These cooperation and agreements show a great integration and enhanced economic links between GCC countries, which is an integral element of any monetary union (Mansoorian \& Neaime, 2002, 2003). Neaime (2000) pointed out that the debate on the advantages and disadvantages of "Flexible versus Fixed exchange rates between GCC countries" is addressed by many researchers.

Jadresic (2002) suggested that a common currency in GCC countries would be worthwhile in an IMF report. If implemented appropriately, it would enhance the economic efficiency and deepen regional integration of GCC countries. Laabas and Limam (2002) also write about the readiness of GCC countries to form the Monetary union. Jadresic (2002) favored the monetary union among GCC 
countries and concluded in his research that the launch of a GCC common currency would be highly beneficial for the region. Darrat and Al-Shamsi (2003) also tested the co-integration among GCC countries and determined that GCC countries are well-matched to create a monetary union. Hebous (2006) concluded that the formation of monetary union among GCC countries is beneficial. In another noteworthy study, Louis and Osman (2008) concluded that the establishment of a monetary union is adequately supported by the fact that the aggregate demand $(\mathrm{AD})$ shocks are perceptibly symmetrical, in contrast to the non-oil aggregate supply (AS) shocks which are imperceptibly symmetrical across the GCC countries. Ganguli (2016) investigated the suitability of EMU formation in GCC countries when oil prices will drop as in the previous era.

It is also important to consider that not all researchers supported the idea of EMU in GCC; many opposed this idea. Shotar and Shams (2005), while examining the economics of GCC countries, discovered the difference in economic policies of GCC countries that may decrease the expected benefits of the GCC monetary union. In another study, Abu-Bader and Abu-Qarn (2006) also conclude that GCC countries still need more preparation to form an EMU. Willett (2010) concluded that GCC countries are not exhibiting flexible characteristics to adopt Common currency. AlKholifey and Alreshan (2010) also concluded that there is no chance exists for a common currency in GCC countries.

It is evident from the literature that different researchers studied the possibility of monetary union among GCC; some of them concluded in favor, and some were against. Almost all of them agree that monetary union is a beneficial tool among countries to increase trade. If GCC sets a monetary union, it will help boost trade among GCC countries.

The previous researchers did not examine the exchange rate mechanism and calculate the exchange rate to check its actual implementation. In this research, the same mechanism is recommended, which EMU uses to fix the exchange rates among participant countries. The exchange rate between GCC countries' current currency and the proposed currency is set and rechecked by the Triangular arbitrage method. The exchange rate of the proposed currency is also set with USD.

\section{The Implementation of Euro Model on GCC Countries}

The Maastricht treaty, known as the Treaty of European Union, defined four primary criteria as pre-requisites for joining EMU. This research will apply these criteria of GCC countries to check the suitability of common currency in the GCC region. Following are the four criteria for the implementation of a common currency region.

\subsection{Price Stability}

Inflation is the increase in the price level over a specified period. The concern of fiscal policy is to control output stabilization and inflation. Fiscal policy is also 
supposed to maintain the inflation rate and assess the effect of the zero bound on economic performance.

"Zero bound is the lowest percentage of owed principle that a central bank can set. A zero-bound interest rate typically refers to the process where, by gradual steps, the interest rate approaches zero" (Gunther et al., 2003).

Even though both inflation and deflation negatively influence economic performance, the zero bound constraint reduces the associated risks of deviating from a zero asymmetric. Following the terms in the Maastricht Treaty agreement, the inflation rate in GCC member countries must not be higher than the average inflation rate compared to the best performing three member states. If at all it exceeds, it should not be more than $1.5 \%$ of such average. This is so because the consumer price index is used to measure inflation. Since Kuwait has the highest inflation rate out of all GCC countries, the Price Stability criterion is applied to Kuwait to confirm if it falls within the specified limits. The results obtained are as follows:

Referring to Table 1, the lowest average values of inflations rates are 1.71, 1.80, and 2.11 for Oman, UAE, and KSA, respectively. The overall average of these rates is $1.88 \%[(1.71+1.80+2.11) / 3=1.88]$. Comparing this value with Kuwait's average inflation rate (i.e., $3.33 \%$ ) for the same years, the percentage difference for Kuwait is obtained as $1.35 \%$ [3.23 $-1.88=1.35 \%]$, which is within the prescribed limit (1.5\%) of the Price Stability criterion. Thus, this particular criterion for a Common Gulf Currency is satisfied because most GCC countries' inflation rates do not vary significantly. This could be partly due to the effect of an interest-free banking system derived from the Islamic cultural heritage of all Gulf countries.

\subsection{Fiscal Prudence}

The term refers to the wise and justifiable use of financial resources instead of excessive spending. Maastricht Treaty advocates that all member countries should avoid excessive budget deficit as follows:

- "The ratio of the planned or actual government deficit to GDP at market prices should not exceed 3\%"; and

- "The ratio of government debt to GDP at market prices should not exceed 60\%" (https://ec.europa.eu/commission/presscorner/detail/en/DOC 122 Access on 10-02-2021).

As exhibited in Table 2, that government debt compared to the GDP in all GCC countries does not increase more than the reference value of $60 \%$. So GCC countries successfully fulfill the first clause of this criterion.

As exhibited in Table 3, the budget deficit of all GCC countries does not exceed the reference value of 3\% except Bahrain and Oman. It's worth mentioning here that the data used include the years 2014 to 2015, in which oil prices touched the lowest level in history. Both countries' GDP mainly rely on oil, so after the stability of oil prices, both countries are stabilizing, and in 2019, the 
Table 1. Average inflation rates (\%), (2011 to 2017).

\begin{tabular}{cc}
\hline Country & Inflation Rates \\
\hline KSA & 2.11 \\
UAE & 1.80 \\
Qatar & 2.18 \\
Oman & 1.71 \\
Bahrain & 2.05 \\
Kuwait & 3.23 \\
\hline
\end{tabular}

(Source: Compiled from Statista (Economic Data Website) Accessed on 10-3-2021).

Table 2. Government debt to GDP (Average 2011 to 2017).

\begin{tabular}{cc}
\hline Country & Government Debt to GDP \\
\hline KSA & 6.9 \\
UAE & 18.65 \\
Qatar & 40.62 \\
Oman & 14.95 \\
Bahrain & 56.21 \\
Kuwait & 7.12 \\
\hline
\end{tabular}

(Source: Compiled from Trading Economics Data Accessed on 10-3-2021).

Table 3. Government deficit or surplus to GDP (Average 2011 to 2017).

\begin{tabular}{cc}
\hline Country & Government Deficit to GDP \\
\hline KSA & -1.75 (Deficit) \\
UAE & 3.11 (Surplus) \\
Qatar & 4.51 (Surplus) \\
Oman & -8.0 (Deficit) \\
Bahrain & -5.34 (Deficit) \\
Kuwait & 19.20 (Surplus) \\
\hline
\end{tabular}

(Source: Compiled from Trading Economics Data Accessed on 10-3-2021).

deficit for Bahrain reduced to -3.5 and Oman -7 . Also, the difference is not very huge. By that time, all the procedures of monetary union will be established; both countries will recover their deficit. This study did not include the latest data because of the COVID-19 exceptional situation, which will not show the actual attainment of any country.

\subsection{Exchange Rate Mechanism (ERM)}

Maastricht Treaty states that all participant member states must be within the normal fluctuation margins provided by the ERM of the Regional Monetary System, for at least two years, without devaluating against any other participant member country currency. GCC countries have been trading with their curren- 
cies pegged with USD for a decade. The only exception is Kuwait which delinked its currency from the USD peg and continued with a basket of currencies. This basket of currency also includes USD.

The European Union used the Triangular Arbitrage method to fix the currency exchange rates with Euro for all the EU member countries. Triangular Arbitrage is a financial activity that is used to find the gaps or arbitrage opportunities between three different currencies. According to Moosa (2001), Triangular Arbitrage is a method of interaction between currencies. It is a very effective method to find the deviation of exchange rates between currencies. In this method, the exchange rates of three currencies are compared using pair-wise comparison. For example, we have currency A, B, and C. First, currency A will be exchanged with currency B, and then currency B will be exchanged with currency C. Finally, currency $\mathrm{C}$ will be exchanged back with currency A. If the final amount of currency A is the same as the initial, then no deviation is found, and currency A has a fixed exchange rate. If the final amount is different from the initial amount, the exchange rate of Currency A is not fixed. In the current study, the researcher applied the triangular arbitrage method on GCC countries to check the deviation and fix the exchange rates with the proposed common currency.

Table 4 displays the exchange rates of AED with the other GCC countries using Triangular Arbitrage. It is evident from the results that exchange rates between GCC countries are consistent. The researcher has computed the exchange rates for all the GCC countries using the Triangular arbitrage method as displayed in Appendix 1. It is seen that all the GCC currencies are consistent in terms of exchange rates. So this criterion on ERM under the Maastricht treaty is satisfied.

\subsection{Interest-Rate Convergence}

The criteria state that "The durability of convergence must be reflected in the long-term interest rate levels." An average long-term interest rate of member states must not exceed $2 \%$ from the average of those three countries with the bottommost long-term interest rates in the region. Comparable securities or Government bonds are the sources of measuring long-term inters rates.

Taking the three lowest interest rates (Table 5) among GCC countries which are 3.0\% (Oman), 3.0\% (Saudi Arabia) and 2.9\% (Bahrain), the overall average

Table 4. Exchange rate of AED through triangular arbitrage.

\begin{tabular}{cccccccc}
\hline A & B & \multicolumn{3}{c}{ C } & & A \\
\hline USD & AED & BHD & KWD & OMR & QAR & SAR & USD \\
\hline 1000 & 3680 & 378 & & & & & 1000 \\
1000 & 3680 & & 294.85 & & & & 1000 \\
1000 & 3680 & & & 385 & & & 1000 \\
1000 & 3680 & & & & 3640 & & 1000 \\
1000 & 3680 & & & & & 3524.5 & 1000 \\
\hline
\end{tabular}


interest rate is obtained as $2.96 \%$. As seen from Table 4, no GCC country has an interest rate of more than $4.96 \%$, which is equal to (Overall Average Interest Rate $+2 \%)$. Thus this criterion of the Maastricht Treaty is also satisfied.

By applying the Maastricht Treaty criteria, it is evident that all GCC countries satisfy the stipulated criteria for establishing a common currency or monetary union, provided they follow the rules of the European Monetary Union (EMU). In fact, EMU is the only model which is an example of the successful implementation of monetary union. Furthermore, the researcher checked the appropriateness of the GCC monetary union by applying the criteria of setting exchange rates and Euro rates to GCC countries described in the next section.

\section{Exchange Rate Mechanism for the Proposed Common Currency}

The researcher has suggested an exchange rate and value for the proposed currency, whose name is "Khaleeji" as called by many GCC experts. The researcher proposed an abbreviation for this currency as "KHJ". Besides, "KHJ" is not used by any currency in the world; it also presents a clear understanding of the word Khaleeji.

The researcher applied the same method which was used for fixing the exchange rate of the Euro. The researcher calculated the average exchange rates with USD for all the six GCC countries. This value which is 1.984 , is considered a value of Khaleeji where $1 \mathrm{USD}=1.984 \mathrm{KHJ}$ as displayed in Table 6 .

Table 5. GCC countries interest rates 2019.

\begin{tabular}{cc}
\hline Country & Interest Rate \\
\hline KSA & 3.0 \\
UAE & 3.0 \\
Qatar & 4.5 \\
Oman & 3.0 \\
Bahrain & 2.9 \\
Kuwait & 3.0 \\
\hline
\end{tabular}

(Source: Compiled from Trading Economics Data Accessed on 10-3-2021)).

Table 6. Calculation for $\mathrm{KHJ}$ value.

\begin{tabular}{cccc}
\hline Country & Currency & USD & KHJ \\
\hline Bahrain & 1 BHD & 2.631 & 0.18796 \\
Kuwait & 1 KWD & 3.333 & 0.14839 \\
Oman & 1 OMR & 2.564 & 0.19291 \\
Qatar & 1 QAR & 0.274 & 1.80049 \\
Saudi Arabia & 1 SAR & 0.266 & 1.85490 \\
U.A.E. & 1 AED & 0.272 & 1.81533 \\
G.C.C. & 1 KHJ & 2.021667 & \\
\hline
\end{tabular}


Table 7. The exchange rate of BHD to $\mathrm{KHJ}$ through triangular arbitrage.

\begin{tabular}{cccccccc}
\hline A & B & \multicolumn{3}{c}{ C } & & A \\
\hline KHJ & BHD & KWD & OMR & QAR & SAR & AED & KHJ \\
\hline 1000 & 187.96 & 148.39 & & & & & 1000 \\
1000 & 187.96 & & 192.91 & & & 1000 \\
1000 & 187.96 & & & 1800.49 & & & 1000 \\
1000 & 187.96 & & & & 1854.90 & & 1000 \\
1000 & 190.55 & & & & & 1815.33 & 1000 \\
\hline
\end{tabular}

Table 8. Exchange rates matrix of GCC currencies.

\begin{tabular}{cccccccc}
\hline Country & Currency & Bahrain & Kuwait & Oman & Qatar & KSA. & UAE. \\
\hline \multirow{2}{*}{ Bahrain } & 1 BHD & 1.000 & 0.789 & 1.026 & 9.578 & 9.868 & 9.657 \\
Kuwait & 1 KWD & 1.266 & 1.000 & 1.3 & 12.133 & 12.5 & 12.233 \\
Oman & 1 OMR & 0.974 & 0.769 & 1.000 & 9.333 & 9.615 & 9.410 \\
Qatar & 1 QAR & 0.104 & 0.082 & 0.107 & 1.000 & 1.030 & 1.008 \\
KSA & 1 SAR & 0.101 & 0.08 & 0.104 & 0.970 & 1.000 & 0.978 \\
UAE & 1 AED & 0.103 & 0.081 & 0.106 & 0.991 & 1.021 & 1.000 \\
\hline
\end{tabular}

To test the viability of this value, the researcher checked the exchange rates of all the GCC countries with Khaleeji using the Triangular Arbitrage method as displayed in Table 7 as an example of one country. The Tables for others are displayed in Appendix 2. The matrix of all the currency exchange rates is also displayed in Table 8.

\section{Conclusion}

The results indicate that GCC states are adequately seasoned to form a common currency or monetary union. It was proved that all the GCC states successfully fulfill the Maastricht Criteria, which is the basis of EMU formation. In reality, many European countries that are now part of the Eurozone were not initially able to fulfill all the criteria successfully. However, they were admitted to the Eurozone, few years after its formation. In GCC countries, all the member states are exceptionally alike in several ways, and their currencies are already pegged with USD except KWD. The state of Kuwait is pegged with a basket of currency, and the basket includes USD, too. The researcher calculated the exchange rates for the Khaleeji, a newly proposed currency. Results indicate that the rules that form the foundation of the Euro Model can be applied effectively in the case of the "GCC Monetary Union", too, without any problem. The increased trading transactions among European states and the strength of the Euro as the one and only competitor to USD show that the proposed GCC Monetary Union will enjoy the same advantages. Furthermore, the "Khaleeji" can become the most vital 
world currency because the GCC countries put together to form the leading oil trading conglomerate in the world.

\section{Limitations and Areas of Future Research}

The research uses the data prior to the COVID-19 pandemic; it is recommended to revalidate the model once the pandemic is over.

\section{Conflicts of Interest}

The author declares no conflicts of interest regarding the publication of this paper.

\section{References}

Abu-Bader, S., \& Abu-Qarn, A. (2006). On the Optimality of a GCC Monetary Union: Structural VRA, Common Trends and Common Cycles Evidence. Ben-Gurion University of the Negev. https://doi.org/10.2139/ssrn.950197

Alagidede, P., \& Ibrahim, M. (2017). On the Causes and Effects of Exchange Rate Volatility on Economic Growth: Evidence from Ghana. Journal of African Business, 18, 169-193. https://doi.org/10.1080/15228916.2017.1247330

AlKholifey, A., \& Alreshan, A. (2010). GCC Monetary Union. IFC, Bulletin No. 32.

Allen, D. E., McAleer, M., Peiris, S., \& Singh, A. K. (2016). Nonlinear Time Series and Neural-Network Models of Exchange Rates between the US Dollar and Major Currencies. Risks, 4, 7. https://doi.org/10.3390/risks4010007

Baldwin, R., \& Taglioni, D. (2007). Trade Effects of the Euro. Journal of Economic Integration, 22, 780-818. https://doi.org/10.11130/jei.2007.22.4.780

Baldwin, R., Nino, V. D., Fontagné, L., De Santis, R., \& Taglioni, D. (2008). Study on the Impact of the Euro on Trade and Foreign Direct Investment. European Economic and Monetary Union Working Paper No. 321. https://doi.org/10.2139/ssrn.1163774

Berger, H., \& Nitsch, V. (2008). Zooming Out: The Trade Effect of the Euro in Historical Perspective. Journal of International Money and Finance, 27, 1244-1260.

https://doi.org/10.1016/j.jimonfin.2008.07.005

Bergsten, C. F., \& Park, Y. C. (2002). Toward Creating a Regional Monetary Arrangement in East Asia. ADB Institute Research Paper No. 50.

Bostan, I., \& Firtescu, B.-N. (2019). Exchange Rate Effects on International Commercial Trade Competitiveness. Journal of Risk and Financial Management, 11, 19.

https://doi.org/10.3390/jrfm11020019

Dal Bianco, S., \& Loan, N. C. T. (2017). FDI Inflows, Price and Exchange Rate Volatility: New Empirical Evidence from Latin America. International Journal of Financial Studies, 5, 6. https://doi.org/10.3390/ijfs5010006

Darrat, A., \& Al-Shamsi, F. (2003). On the Path to Integration in the Gulf Region: Are the Gulf Economies Sufficiently Compatible?

De Nardis, S., De Santis, R., \& Vicarelli, C. (2008a). The Euro's Effects on Trade in a Dynamic Setting. European Journal of Comparative Economics, 5, 73-85. https://doi.org/10.2139/ssrn.979956

De Nardis, S., De Santis, R., \& Vicarelli, C. (2008b). The Single Currency's Effects on Eurozone Sectoral Trade: Winners and Losers? Economics E-Journal, 2, 1-34.

https://doi.org/10.5018/economics-ejournal.ja.2008-17 
De Sousa, J. (2012). The Currency Union Effect on Trade Is Decreasing over Time. Economics Letters, 117, 917-920. https://doi.org/10.1016/j.econlet.2012.07.009

Eichengreen, B., \& Hausmann, R. (1999). Exchange Rates and Financial Fragility (pp. 329-368). Proceedings, Federal Reserve Bank of Kansas City.

https://doi.org/10.3386/w7418

European Central Bank (2021). Convergence Criteria. https://eur-lex.europa.eu/legal-content/EN/TXT/PDF/?uri=CELEX:11992M/TXT\&fro $\underline{\mathrm{m}=\mathrm{EN}}$

Flam, H., \& Nordstrom, H. (2006). Euro Effects on the Intensive and Extensive Margins of Trade. CESifo Working Paper Series 1881.

Flandreau, M., \& Maurel, M. (2001). Monetary Union, Trade Integration, and Business Cycles in 19th Century Europe: Just Do It. CEPR Discussion Papers 3087.

Frankel, J. A., \& Rose, A. K. (2002). An Estimate of the Effect of Currency Unions on Trade and Income. The Quarterly Journal of Economics, 117, 437-466.

http://www.jstor.org/stable/2696432

Ganguli, S. (2016). An Economic Analysis of Sustainability of a Potential GCC Economic and Monetary Union during 2005-2014. World Journal of Entrepreneurship, Management and Sustainable Development, 12, 194-206. https://doi.org/10.1108/WJEMSD-01-2016-0005

Gębarowski, R., Oświęcimka, P., Wątorek, M., et al. (2019). Detecting Correlations and Triangular Arbitrage Opportunities in the Forex by Means of Multifractal Detrended Cross-Correlations Analysis. Nonlinear Dynamics, 98, 2349-2364. https://doi.org/10.1007/s11071

Glick, R. (2017). Currency Unions and Regional Trade Agreements: EMU and EU Effects on Trade. Comparative Economic Studies, 59, 194-209. https://doi.org/10.1057/s41294-017-0020-x

Glick, R., \& Rose, A. K. (2016). Currency Unions and Trade: A Post-EMU Reassessment. European Economic Review, 87, 78-91. https://doi.org/10.1016/j.euroecorev.2016.03.010

Gulzar, W. A. (2015). Enrichment in OCA Theory: Towards a Robust Model for Optimum Currency Area by Inclusion of Culture Criteria. Life Science Journal, 12, 16-24.

Gunther, C., Orphanides, A., \& W, V. (2003). Price Stability and Monetary Policy Effectiveness When Nominal Interest Rates Are Bounded at Zero. Working Paper Series No. 231, European Central Bank.

Hatmanu, M., Căutisanu, C., \& Ifrim, M. (2020). The Impact of Interest Rate, Exchange Rate and European Business Climate on Economic Growth in Romania: An ARDL Approach with Structural Breaks. Sustainability, 12, 2798.

https://doi.org/10.3390/su12072798

Havranek, T. (2010). Rose Effect and the Euro: Is the Magic Gone? Review of World Economics, 146, 241-261. https://doi.org/10.1007/s10290-010-0050-1

Head, K. and Mayer, T. (2014). Gravity Equations: Workhorse, Toolkit, and Cookbook (Vol. 4). In G. Gopinath, E. Helpman, \& K. Rogoff (Eds.), Handbook of International Economics. Elsevier, 131-195.

Hebous, S. (2006). On the Monetary Union of the Gulf States. The Kiel Institute for the World Economy.

Ioan, B., Mozi, R. M., Lucian, G., Gheorghe, F., Horia, T., Ioan, B., \& Mircea-Iosif, R. (2020). An Empirical Investigation on Determinants of Sustainable Economic Growth. 
Lessons from Central and Eastern European Countries. Journal of Risk and Financial Management, 13, 146. https://doi.org/10.3390/jrfm13070146

Jadresic, E. (2002). On a Common Currency for the GCC Countries. IMF Policy Discussion Paper (PDP/02/12).

Jamil, M., Streissler, E. W., \& Kunst, R. M. (2012). Exchange Rate Volatility and Its Impact on Industrial Production, before and after the Introduction of Common Currency in Europe. International Journal of Economics and Financial Issues, 2, 85-109.

Kenen, P. (1969). The Theory of Optimum Currency Areas: An Eclectic View. University of Chicago Press.

Laabas, B., \& Limam, I. (2002). Are GCC Countries Ready for Currency Union? Arab Planning Institute.

Latief, R., \& Lefen, L. (2018). The Effect of Exchange Rate Volatility on International Trade and Foreign Direct Investment (FDI) in Developing Countries along "One Belt and One Road". International Journal of Financial Studies, 6, 86. https://doi.org/10.3390/ijfs6040086

Lopez Cordova, J. E., \& Meissner, C. (2001). Exchange-Rate Regimes and International Trade: Evidence from the Classical Gold Standard Era. University of California.

Louis, B., \& Osman (2008). Monetary Union among Arab Gulf Cooperation Council (AGCC) Countries: Does the Symmetry of Shocks Extend to the Non-Oil Sector? Munich Personal RePEc Archive.

Mansoorian, A., \& Neaime, S. (2002). Habits and Durability in Consumption and the Effects of Exchange Rate Policies. International Economic Journal, 16, 97-114. https://doi.org/10.1080/10168730200080016

Mansoorian, A., \& Neaime, S. (2003). Durable Goods, Habits, Time Preference, and Exchange Rates. North American Journal of Economics and Finance, 14, 115-130. https://doi.org/10.1016/S1062-9408(02)00115-8

McIver, I. (2011). The European Union-A Brief History. The Scottish Parliament. https://www.scottish.parliament.uk

McKinnon, R. (1963). Optimum Currency Area. American Economic Review, 53, 717-725.

Moosa (2001). Triangular Arbitrage in the Spot and Forward Foreign Exchange Markets. Quantitative Finance, 1, 387-390. https://doi.org/10.1080/713665833

Mundell, R. (1961). A Theory of Optimum Currency Areas. American Economic Review, 51, 657-665.

Neaime, S. (2000). The Macroeconomics of Exchange Rate Policies, Tariff Protection and the Current Account: A Dynamic Framework. APF Press.

Priewe, J. (2007). Reconsidering the Theories of Optimum Currency Area-A Critique. In E. Hein, J. Priewe, \& A. Truger (Eds.), European Integration in Crisis (pp. 27-52). Marburg/Lahn, Metropolis.

Rjoub, H. (2012). Stock Prices and Exchange Rates Dynamics: Evidence from Emerging Markets. African Journal of Business Management, 6, 4728-4733.

https://doi.org/10.5897/AJBM11.2761

Rose, A. (2008). Is EMU Becoming an Optimum Currency Area? The Evidence on Trade and Business Cycle Synchronization.

Rose, A. K. (2000). One Money One Market: Estimating the Effect of Common Currencies on Trade. Economic Policy: A European Forum, 30, 7-45.

https://doi.org/10.1111/1468-0327.00056 
Santos Silva, J. M. C., \& Tenreyro, S. (2010). Currency Unions in Prospect and Retrospect. Annual Review of Economics, 2, 51-74.

https://doi.org/10.1146/annurev.economics.102308.124508

Schnabl, G. (2008). Exchange Rate Volatility and Growth in Small Open Economies at the EMU Periphery. Economic Systems, 32, 70-91.

https://doi.org/10.1016/j.ecosys.2007.06.006

Shotar, M., \& Shams, K. (2005). Economic Policies and the Possibilities of Unified GCC Currency. University of Qatar. (In Arabic)

Siroën, J.-M. (2004). The Regionalization of the World Economy. La Découverte publisher. https://doi.org/10.3917/dec.siroe.2004.01

Statista (Economic Data Website). https://www.statista.com

Trading Economics Data. https://tradingeconomics.com

Treaty (1992). Treaty on European Union. Official Journal of the European Communities.

https://eur-lex.europa.eu/legal-con-tent/EN/TXT/PDF/?uri=CELEX:11992M/TXT\&fro $\underline{\mathrm{m}}=\mathrm{LV}$

Vo, D. H., \& Zhang, Z. Y. (2019). Exchange Rate Volatility and Disaggregated Manufacturing Exports: Evidence from an Emerging Country. Journal of Risk and Financial Management, 12, 12. https://doi.org/10.3390/jrfm12010012

Willett, T. D. (2010). The GCC's Fixed Exchange Rate: A Major Anomaly for OCA Analysis. The World Economy, 33, 1702-1717.

https://doi.org/10.1111/j.1467-9701.2010.01301.x 
Appendix 1. Triangular Arbitrage Constructed for Analysis of GCC Currencies

\begin{tabular}{ccccccc}
\hline & Bahrain & Kuwait & Oman & Qatar & Saudi Arabia & U.A.E. \\
\hline & BHD & KWD & OMR & QAR & SAR & AED \\
\hline 1 BHD & 1 & 0.789473684 & 1.026315789 & 9.578947368 & 9.868421053 & 9.657894737 \\
1 KWD & 1.266666667 & 1 & 1.3 & 12.13333333 & 12.5 & 12.23333333 \\
1 OMR & 0.974358974 & 0.769230769 & 1 & 9.333333333 & 9.615384615 & 9.41025641 \\
1 QAR & 0.104395604 & 0.082417582 & 0.107142857 & 1 & 1.03021978 & 1.008241758 \\
1 SAR & 0.101333333 & 0.08 & 0.104 & 0.970666667 & 1 & 0.978666667 \\
1 AED & 0.103542234 & 0.081743869 & 0.10626703 & 0.991825613 & 1.021798365 & 1 \\
\hline
\end{tabular}

BHD:

\begin{tabular}{cccccccc}
\hline A & B & & \multicolumn{3}{c}{ C } & & A \\
\hline USD & BHD & KWD & OMR & QAR & SAR & AED & USD \\
\hline 1000 & 380 & 300 & & & & & 1000 \\
1000 & 380 & & \multirow{2}{*}{390} & & & 1000 \\
1000 & 380 & & & 3640 & & & 1000 \\
1000 & 380 & & & & 3750 & & 1000 \\
1000 & 380 & & & & & 3670 & 1000 \\
\hline
\end{tabular}

KWD:

\begin{tabular}{cccccccc}
\hline A & B & & \multicolumn{3}{c}{ C } & & A \\
\hline USD & KWD & OMR & QAR & SAR & AED & BHD & USD \\
\hline 1000 & 300 & 390 & & & & & 1000 \\
1000 & 300 & & 3640 & & & 1000 \\
1000 & 300 & & & 3750 & & & 1000 \\
1000 & 300 & & & & 3670 & & 1000 \\
1000 & 300 & & & & & 380 & 1000 \\
\hline
\end{tabular}

OMR:

\begin{tabular}{cccccccc}
\hline A & B & & \multicolumn{3}{c}{ C } & & A \\
\hline USD & OMR & QAR & SAR & AED & BHD & KWD & USD \\
\hline 1000 & 390 & 3640 & & & & & 1000 \\
1000 & 390 & & 3750 & & & 1000 \\
1000 & 390 & & & 3670 & & & 1000 \\
1000 & 390 & & & & 380 & & 1000 \\
1000 & 390 & & & & & 300 & 1000 \\
\hline
\end{tabular}


QAR:

\begin{tabular}{cccccccc}
\hline A & B & & \multicolumn{3}{c}{ C } & & A \\
\hline USD & QAR & SAR & AED & BHD & KWD & OMR & USD \\
\hline 1000 & 3640 & 3750 & & & & & 1000 \\
1000 & 3640 & & 3670 & & & 1000 \\
1000 & 3640 & & & 380 & & & 1000 \\
1000 & 3640 & & & & 300 & & 1000 \\
1000 & 3640 & & & & & 390 & 1000 \\
\hline
\end{tabular}

SAR:

\begin{tabular}{cccccccc}
\hline A & B & & \multicolumn{3}{c}{ C } & & A \\
\hline USD & SAR & AED & BHD & KWD & OMR & QAR & USD \\
\hline 1000 & 3750 & 3670 & & & & & 1000 \\
1000 & 3750 & & 380 & & & 1000 \\
1000 & 3750 & & & 300 & & & 1000 \\
1000 & 3750 & & & & 390 & & 1000 \\
1000 & 3750 & & & & & 3640 & 1000 \\
\hline
\end{tabular}

AED:

\begin{tabular}{cccccccc}
\hline A & B & & \multicolumn{3}{c}{ C } & & A \\
\hline USD & AED & BHD & KWD & OMR & QAR & SAR & USD \\
\hline 1000 & 3670 & 380 & & & & & 1000 \\
1000 & 3670 & & 300 & & & 1000 \\
1000 & 3670 & & & 390 & & & 1000 \\
1000 & 3670 & & & & 3640 & & 1000 \\
1000 & 3670 & & & & & 3750 & 1000 \\
\hline
\end{tabular}


Appendix 2. Original Data Collected for Analysis

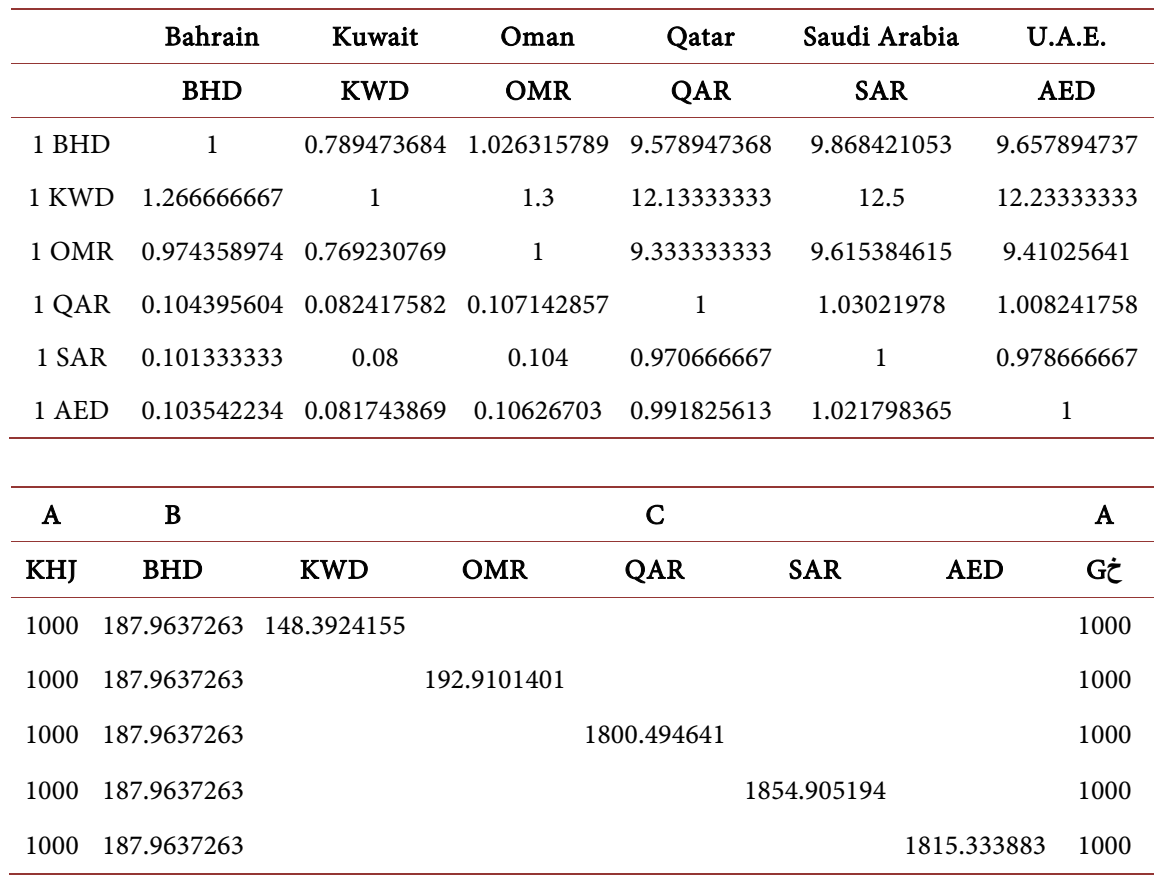

\begin{tabular}{cccccccc}
\hline A & B & \multicolumn{3}{c}{ C } & & A \\
\hline Gं & KWD & OMR & QAR & SAR & AED & BHD & Gं \\
\hline 1000 & 148.3924155 & 192.9101401 & & & & & 1000 \\
1000 & 148.3924155 & & 1800.494641 & & & & 1000 \\
1000 & 148.3924155 & & & 1854.905194 & & 1000 \\
1000 & 148.3924155 & & & & 1815.333883 & & 1000 \\
1000 & 148.3924155 & & & & 187.9637263 & 1000 \\
\hline
\end{tabular}

\begin{tabular}{cccccccc}
\hline A & B & \multicolumn{3}{c}{ C } & & & A \\
\hline Gi & OMR & QAR & SAR & AED & BHD & KWD & Gं \\
\hline 1000 & 192.9101401 & 1800.494641 & & & & & 1000 \\
1000 & 192.9101401 & & 1854.905194 & & & 1000 \\
1000 & 192.9101401 & & & 1815.333883 & & 1000 \\
1000 & 192.9101401 & & & & 187.9637263 & & 1000 \\
1000 & 192.9101401 & & & & 148.3924155 & 1000 \\
\hline
\end{tabular}

\begin{tabular}{cccccccc}
\hline A & B & \multicolumn{3}{c}{ C } & & & A \\
\hline Gं & QAR & SAR & AED & BHD & KWD & OMR & Gं \\
\hline 1000 & 1800.494641 & 1854.905194 & & & & & 1000 \\
1000 & 1800.494641 & & 1815.333883 & & & & 1000 \\
1000 & 1800.494641 & & & 187.9637263 & & 1000 \\
1000 & 1800.494641 & & & 148.3924155 & & 1000 \\
1000 & 1800.494641 & & & & 192.9101401 & 1000 \\
\hline
\end{tabular}




\begin{tabular}{|c|c|c|c|c|c|c|c|}
\hline A & B & & & $\mathrm{C}$ & & & A \\
\hline $\mathrm{G} \dot{\check{C}}$ & SAR & AED & BHD & KWD & OMR & QAR & $\mathrm{G} \dot{z}$ \\
\hline 1000 & 1854.905194 & 1815.333883 & & & & & 1000 \\
\hline 1000 & 1854.905194 & & 187.9637263 & & & & 1000 \\
\hline 1000 & 1854.905194 & & & 148.3924155 & & & 1000 \\
\hline 1000 & 1854.905194 & & & & 192.9101401 & & 1000 \\
\hline 1000 & 1854.905194 & & & & & 1800.494641 & 1000 \\
\hline A & B & & & C & & & A \\
\hline $\mathrm{G} \dot{\mathrm{C}}$ & AED & BHD & KWD & OMR & QAR & SAR & $\mathrm{G} \dot{\mathrm{C}}$ \\
\hline 1000 & 1815.333883 & 187.9637263 & & & & & 1000 \\
\hline 1000 & 1815.333883 & & 148.3924155 & & & & 1000 \\
\hline 1000 & 1815.333883 & & & 192.9101401 & & & 1000 \\
\hline 1000 & 1815.333883 & & & & 1800.494641 & & 1000 \\
\hline 1000 & 1815.333883 & & & & & 1854.905194 & 1000 \\
\hline
\end{tabular}

